\title{
Peningkatan Kemampuan Representasi Matematis Siswa SMP pada Materi Diagram Venn melalui Pendekatan Realistic Matematis Education
}

\author{
${ }^{1}$ Sartika Duwila, ${ }^{2}$ Ikram Hamid, ${ }^{3}$ Ariyanti Jalal \\ ${ }^{1,2,3}$ Program Studi Pendidikan Matematika, Universitas Khairun
}

\begin{abstract}
ABSTRAK
Penelitian eksperimen ini bertujuan untuk mengetahui 1) kemampuan representasi matematis siswa kelas VII pada materi Diagram Venn melalui pendekatan matematika Realistik, 2) pendekatan matematika Realistik dapat meningkatkan kemampuan reprsentasi matematis siswa dalam menyelesaikan Diagram Venn.

Penelitian ini menggunakan desain penelitian One Group Pretest-Posttes Design dan menjadikan siswa kelas VII yang berjumlah 38 siswa sebagai sampel penelitian. Data penelitian dikumpulkan melalui teknik tes untuk mengetahui peningkatan kemampuan representasi matematis siswa terhadap penerapan model Realistic Mathematics Education (RME). Teknik analisis data menggunakan rumus PAP, N.Gain (g), uji Normalitas, dan uji Hipotesis.

Hasil tes penelitian dianalisis untuk memperoleh tingkat kemampuan siswa dalam menyelesaikan soal dengan kualifikasi sebagai berikut: kualifikasi memuaskan sebesar 78,94\% dan kualifikasi baik sebesar 21,05\%. Pada taraf nyata $\alpha=0,05$ diperoleh $\mathrm{t}_{\text {hitung }}=2,88>\mathrm{t}_{\text {tabel }}=1,684$. Oleh karena itu hipotesis $\mathrm{H}_{0}$ ditolak, yang berarti bahwa terdapat peningkatan kemampuan representasi matematis siswa tergolong tinggi dengan nilai N Gain yang diperoleh yakni 0,88. Dengan demikian terdapat peningkatan kemampuan representasi matematis siswa melalui model pendekatan RME pada siswa SMP Negeri 4 Mangoli Selatan.
\end{abstract}

Kata Kunci : Realistik Matematis Education, Kemampuan Representasi, Diagram Venn.

\section{PENDAHULUAN}

Pendidikan merupakan media yang sangat berperan untuk menciptakan manusia yang berkualitas dan berpotensi. Karena melalui pendidikan akan terjadi proses pendewasaan diri sehingga di dalam proses pengambilan keputusan terhadap suatu masalah yang dihadapi selalu disertai dengan rasa tanggung jawab. Mengingat peran pendidikan tersebut maka sudah seharusnya aspek ini menjadi perhatian pemerintah dalam rangka meningkatkan sumber daya masyarakat indonesia yang berkualitas.

Menurut Hamalik (2004: 5) peningkatan hasil belajar siswa tidak terlepas dari berbagai faktor yang mempengaruhinya. Dalam hal ini diperlukan guru yang dapat membuat pembelajaran menjadi lebih menarik dan disukai oleh peserta didik. Suasana 
kelas perlu direncanakan dan dibangun sedemikian rupa dengan menggunakan model pembelajaran yang tetap agar siswa dapat memperoleh kesempatan untuk berinteraksi satu sama lain sehingga pada gilirannya dapat memperoleh hasil pembelajaran yang optimal.

Perkembangan ilmu pengetahuan dan teknologi tidak terlepas dari perkembangan matematika yang merupakan salah satu cabang dari ilmu pengetahuan yang sangat penting. Hal ini yang mendasari matematika wajib untuk diajarkan kepada siswa. Namun sampai sekarang bagi siswa, ilmu matematika cenderung sulit dipelajari dan dipahami, sehingga siswa tidak mampu menguasai materi yang menyebabkan siswa belum mencapai nilai Kriteria Ketuntasan Maksimal (KKM).

Berdasarkan hasil wawancara dengan guru matematika yang dilakukan peneliti dengan salah satu guru matematika di kelas VII SMP Negeri 4 Mangoli Selatan pada tanggal 19 September 2015 menyatakan bahwa: (1) minat belajar sebagian siswa di kelas VII pada pelajaran matematika masih kurang (2) Model pembelajaran yang biasa kami atau guru gunakan adalah pengajaran langsung berupa penyampaian materi lewat ceramah, latihan dan memberikan tugas-tugas (3) dalam proses pembelajaran berlangsung siswa kurang aktif (4) hasil nilai ulangan harian di kelas VII SMP Negeri 4 Mangoli Selatan untuk matematika masih sangat rendah karena belum tercapai hasil KKM yang ditentukan.

Pada hasil nilai ulangan harian dapat dilihat pada diagram di bawah ini menunjukan bahwa $25 \%$ hasil siswa yang tuntas dan $75 \%$ hasil siswa yang tidak tuntas. Sedangkan Jumlah siswa kelas VII di SMP Negeri 4 Mangoli Selatan adalah 38 siswa, dan hasil ulangan harian siswa yang dikatakan berhasil adalah 14 siswa dan siswa yang tidak berhasil dalam KKM adalah 24 siswa.

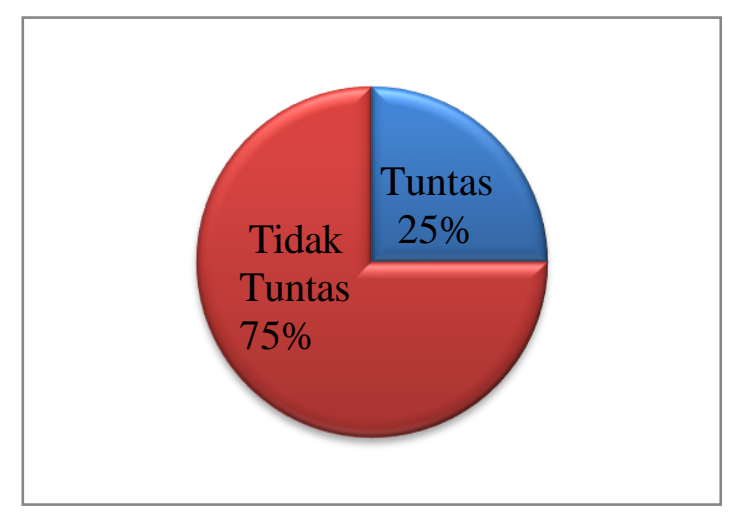

Gambar 1.

Diagram Hasil Ulangan Matematika Siswa SMP Negeri 4 Mangoli Selatan 
Rendahnya hasil belajar siswa disebabkan karena siswa tidak bisa menyelesaikan masalah matematika dan kemampuan representasi siswa masih rendah. Hudiono (2005: 19) menyatakan bahwa "kemampuan representasi dapat mendukung siswa dalam memahami konsep-konsep matematika yang dipelajari dan keterkaitannya 
untuk mengkomunikasikan ide-ide matematika siswa untuk lebih mengenal keterkaitan (koneksi) diantara konsep-konsep matematika.

Pada penjelasan di atas maka dapat disimpulkan bahwa kemampuan reprsentasi matematika siswa masih tergolong rendah. Untuk itu perlu dilakukan suatu pembelajaran yang melibatkan siswa aktif dan kreatif dalam pembelajaran yaitu dengan pendekatan pembelajar RME. Pendekatan pembelajar RME merupakan salah satu pendekatan yang membantu siswa melakukan pemecahan masalah secara kreatif dan menghargai keragaman berfikir yang mungkin timbul selama proses pemecahan masalah. Pendekatan pembelajaran ini memberi siswa kesempatan untuk memperoleh pengetahuan, pengalaman, menemukan, mengenali dan memecahkan masalah dengan beberapa cara yang berbeda serta dapat meningkatkan representasi siswa terhadap suatu masalah.

Pembelajaran matematika semestinya harus menggunakan model pembelajaran yang tepat, sehingga kemampuan matematis dalam pemecahan masalah matematis maupun masalah dalam kehidupan sehari-hari dapat diselesaikan demi pengembangan matematika di masa mendatang. Proses belajar mengajar dalam matematika tidak serta merta hanya dilakukan begitu saja, tetapi guru perlu melakukan bimbingan dan pemahaman kepada siswa sehingga siswa termotivasi, agar dapat memahami konsepkonsep dan teorema-teorema dengan baik, sehingga dapat menggunakan konsepkonsep dan terorema-teorema tersebut sebagai pengetahuan baru dalam memahami matematika.

Salah satu cara untuk mengembangkan kemampuan pemecahan masalah adalah melalui pembelajaran yang tidak hanya memposisikan siswa sebagai pendengar, pemerhati, dan pencatat apa yang diterangkan, diragakan, dan ditulis guru, tetapi pembelajaran yang melibatkan siswa sebagai individu aktif dalam mengkonstruk pengetahuan melalui proses belajar interaktif. Siswa sebagai faktor yang menyusun sendiri pengetahuan melalui pemahaman, pengalaman, dan kemampuan yang dimilikinya.

Pendekatan pembelajaran matematika realistik atau yang biasa dikenal dengan Realistic Mathematics Education (RME) merupakan salah satu alternatif pembelajaran yang tepat karena dengan model pembelajaran ini siswa dituntut untuk mengkontruksi pengetahuan dengan kemampuannya sendiri melalui aktivitas-aktivitas yang dilakukannya dalam kegiatan pembelajaran. Ide utama pembelajaran dengan 
menggunakan pendekatan pembelajaran RME adalah siswa harus diberi kesempatan untuk menemukan kembali (reinvention) konsep matematika dengan bimbingan orang dewasa. Siswa mengembangkan model mereka sendiri sewaktu memecahkan soal-soal kontekstual. Pada awalnya, siswa akan menggunakan model pemecahan yang informal (tidak resmi). Setelah terjadi interaksi dan komujikasi akan berkembang menjadi model yang formal (resmi). Gravemeijer (Laramla, 2014: 25). Selain itu dalam pandangan ini, matematika dipandang sebagai suatu kegiatan manusia.

Representasi adalah ungkapan-ungkapan dari ide matematika yang ditampilkan siswa sebagai model atau bentuk pengganti dari suatu situasi masalah yang digunakan untuk menemukan solusi dari masalah yang sedang dihadapinya sebagai hasil dari interpretasi pikirannya. Suatu masalah dapat direpresentasikan melalui gambar, katakata (verbal), tabel, benda konkrit, atau simbol matematika. Goldin (Nurhayati, 2013: 15) mengatakan bahwa representasi adalah elemen yang sangat penting untuk teori belajar mengajar matematika, tidak hanya karena pemakaian sistem simbolis yang juga penting dalam matematika dan kaya akan kalimat dan kata, beragam dan universal, tetapi juga untuk dua alasan penting yaitu 1) matematika mempunyai peranan penting dalam mengkonsep tualisasi dunia nyata; 2) matematika menjadi lebih mudah (homomorphis) yang merupakan penurunan dari struktur hal-hal yang pokok.

\section{METODE PENELITIAN}

\section{A. Jenis Penelitian dan DesainPenelitian}

Penelitian ini berupa penelitian pre-eksperimen, yang bertujuan untuk meningkatkan kemampuan representasi matematis siswa SMP kelas VII pada materi diagram venn, dengan menggunakan desain penelitian one group pretest-posttes design. Menurut (Sugiyono, 2012: 111) Desain penelitiannya dapat dilihat pada tabel berikut:

\section{Tabel 1.}

\section{Desain Penelitian}

one group pretest-posttes design

\begin{tabular}{|l|l|l|}
\hline $\mathrm{O}_{1}$ & $\mathrm{X}$ & $\mathrm{O}_{2}$ \\
\hline
\end{tabular}

Keterangan :

$\mathrm{O}_{1}=$ Pretest pada kelas eksperimen 
$\mathrm{X}=$ Kelas yang diajarkan dengan menggunakan pendekatan RME

$\mathrm{O}_{2}=$ Posttest pada kelas eksperimen

\section{B. Populasi dan Sampel}

Menurut (Sugiyono 2012: 61) bahwa populasi adalah wilayah generalisasi yang terdiri atas obyek/subyek yang mempunyai kualitas dan karakteristik tetentu,dari pengertian tersebut maka yang menjadi populasi dalam penelitian ini adalah seluruh siswa kelas VII SMP Negeri 4 Mangoli Selatan yang berjumlah 38 orang.

Sampel adalah bagian dari jumlah dan karakteristik yang dimiliki oleh populasi tersebut (Sugiyono, 2012: 62). Sampel yang digunakan untuk penelitian ini adalah siswa kelas VIIyang berjumlah 38 siswa.

\section{Teknik Pengumpulan Data}

\section{Prosedur Penelitian}

a. Melakukan observasi untuk menentukan kelas yang akan dijadikan subjek penelitian

b. Memberikan tes kemampuan awal (pre-test) tentang materi diagram venn.

c. Memberikan perlakuan pada kelas yang menjadi subjek penelitian.

d. Memberikan tes kemampuan akhir (post-test) tentang soal diagram venn.

e. Menilai hasil tes yang diperoleh dengan pembelajarannya menggunakan pendekatan RME.

\section{Instrumen Penelitian}

Bentuk instrumen yang digunakan dalam penelitian adalah bentuk tes. Instrumen tes yang digunakan dalam penelitian ini sebanyak 2 butir soal tes awal yaitu tentang kemampuan representasi matematis.

\section{Teknik Analisis Data}

\section{Analisis Deskriptif}

\section{a. Menghitung Tingkat Penguasaan}

Mengetahui kemampuan representasi matematis siswa SMP Negeri 4 Mangoli Selatan dengan menggunakan pendekatan RME, digunakan kriteria keberhasilan siswa berdasarkan KKM mata pelajaran matematika yang diterapkan oleh SMP Negeri 4 Mangoli Selatan, yaitu setiap siswa di katakan berhasil apabila siswa dalam kelas mendapat nilai 75 .

Proses analisis data mengunakan langkah-langkah sebagai berikut: 
Menghitung presentase dari skor yang dicapai setiap siswa dalan menyelesaikan soal digunakan rumus sebagai berikut:

Menghitung presentase dari skor yang dicapai setiap siswa dalam menyelesaikan soal dengan menggunakan rumus:

$$
P=\frac{\text { skor rata-rata }}{\text { Skor maksimal }} \times 100 \%
$$

Selanjutnya data skor siswa dalam menyelesaikan soal tes kemampuan representasi matematis siswa akan berkualifikasikan dengan menggunakan pedoman acuan patokan (PAP) skala 5(Thoha, 2003: 89).

Tabel 2.

Pedoman Acuan Patokan (PAP) Skala 5

\begin{tabular}{|c|c|}
\hline Taraf Penguasaan & Kualifikasi \\
\hline $91 \%-100 \%$ & Memuaskan \\
\hline $81 \%-90 \%$ & Baik \\
\hline $71 \%-80 \%$ & Cukup \\
\hline $60 \%-70 \%$ & Kurang \\
\hline$<60 \%$ & Gagal \\
\hline
\end{tabular}

\section{b. Menghitung Gain Interpretasi}

Untuk mengetahui peningkatan kemampuan representasi matematika siswa pada materi Diagram Venn, dengan menggunakan rumus N Gain $<$ g $>$ Sundayana R (2014: 151) :

$$
N-\operatorname{gain}(g)=\frac{(\text { skor rata }- \text { rata postest })-(\text { skor rata }- \text { rata pretest })}{\text { skor maksimum }-(\text { skor rata }- \text { rata pretest })}
$$

Tabel 3.

\section{Interpretasi Nilai N-gain}

\begin{tabular}{|c|c|}
\hline Kategori Perolehan N-gain & Interpretasi \\
\hline $\mathrm{g}>0,75$ & Tinggi \\
\hline $0,30<\mathrm{g} \leq 0,75$ & Sedang \\
\hline $\mathrm{g} \leq 0,30$ & Rendah \\
\hline
\end{tabular}

\section{Analisis Inferensial}

Untuk mengetahui pendekatan RME dapat menigkatkan kemampuan 
reresentasi matematis siswa, digunakan uji prasyarat yang terdiri atas uji normalitas.

\section{a. Uji Prasyarat}

1) Uji normalitas

Sugiyono (2012: 75-79) menyatakan bahwa uji normalitas digunakan untuk statistik yang akan digunakan dalam mengolah data, yang paling penting adalah untuk menentukan apakah menggunakan statistik parametrik atau nonparametrik. Sehingga rumus yang digunakan adalah Chi-kuadrat.

\section{b. Uji Hipotesis}

Pengujian hipotesis dalam penelitian ini menggunakan one sample t-test, Pengujian ini dilakukan dengan bantuan sofware SPSS 20.0. Pembelajaran kooperatif tipe NHT dikatakan dapat meningkatkan kemampuan berpikir kreatif matematis siswa apabila ratarata kemampuan siswa 80.80 .

Secara statiik dapat dituliskan sebagai berikut:

$$
\begin{aligned}
& \mathrm{H}_{0}: \mu_{N H T} \leq 80.80 \\
& \mathrm{H}_{1}: \mu_{N H T}>80.80
\end{aligned}
$$

\section{Keterangan.}

$\mathrm{H}_{0}$ : Tidak terdapat peningkatkan kemampuan berpikir kreatif matematis siswa pada materi lingkaran

$\mathrm{H}_{1}$ : Terdapat peningkatkan kemampuan berpikir kreatif matematis siswa pada materi lingkaran menggunakan Model pembelajaran kooperatif tipe NHT

Dengan kriteria pengujian:

Tolak $\mathrm{H}_{0}$ jika t hitung $>t_{\text {tabel }}$

Terima $\mathrm{H}_{0}$ jika t hitung $\leq t_{\text {tabel }}$

\section{HASIL PENELITIAN DAN PEMBAHASAN}

\section{A. Deskripsi Data Hasil Penelitian}

1. Kemampuan representasi matematis siswa kelas VII pada materi Diagram Venn melalui pendekatan matematika Realistik

Dari hasil penelitian ini diperoleh melalui tes awal pada tanggal 18 Mei 2016 dari 38 siswa kelas VII di SMP Negeri 4 Mangoli Selatan dan tes akhir pada tanggal 28 Mei 2016. Berdasarkan hasil tes tersebut rata-rata hasil tes siswa pada kelas RME adalah 93,94. Nilai rata-rata yang diperoleh menunjukan bahwa tingkat kemampuan 
representasi matematis pada materi diagram venn mencapai 93,94\%. Dapat di lihat pada grafik hasil tes akhir pada kelas RME setelah dikonversi ke PAP skala 5 terdapat 30 siswa (78,94\% ) kualifikasi memuaskan dan 8 siswa (21,05\% ) kualifikasi baik.

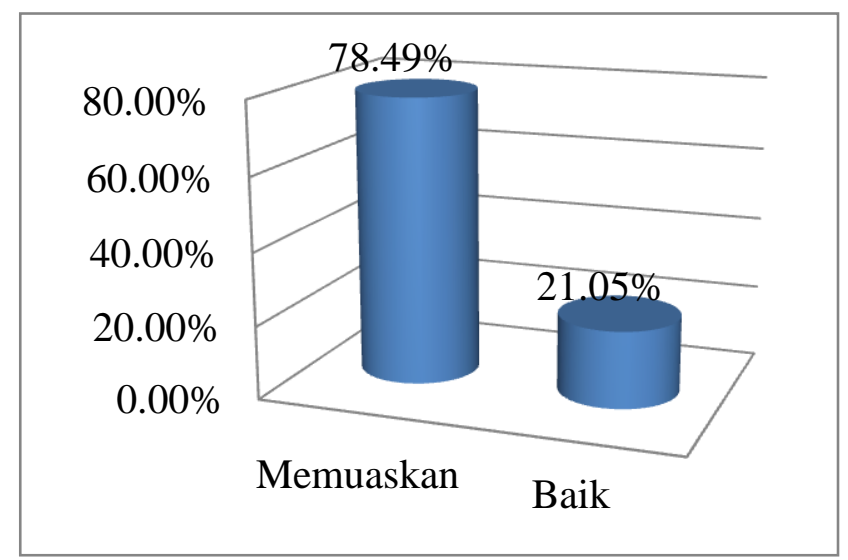

Gambar 2.

Grafik PAP skala 5 pada kelas eksperimen 


\section{Pendekatan Matematika Realistik Dapat Meningkatkan Kemampuan}

\section{Representasi Matematis Siswa Dalam Menyelesaikan Diagram Venn}

Pendekatan RME dapat meningkatkan kemampuan representasi matematis

siswa kelas VII SMP Negeri 4 Mangoli Selatan pada tes akhir yang diperoleh Gain = 0,88 yang diinterpretasikan tinggi dengan nilai rata-rata siswa 93,94. Hasil tes awal pada kelas eksperimen terdapat 38 siswa, 4 siswa (10,52\%) kualifikasi baik, 7 siswa $(18,42 \%)$ kualifikas kurang, dan 27 siswa $(71,05 \%)$ kualifikasi gagal. Sedangkan pada hasil tes akhir pada kelas eksperimen terdapat 30 siswa (78,49\%) kualifikasi memuaskan dan 8 siswa $(21,05 \%)$ kualifikasi baik.

Tes awal pada kelas eksperimen

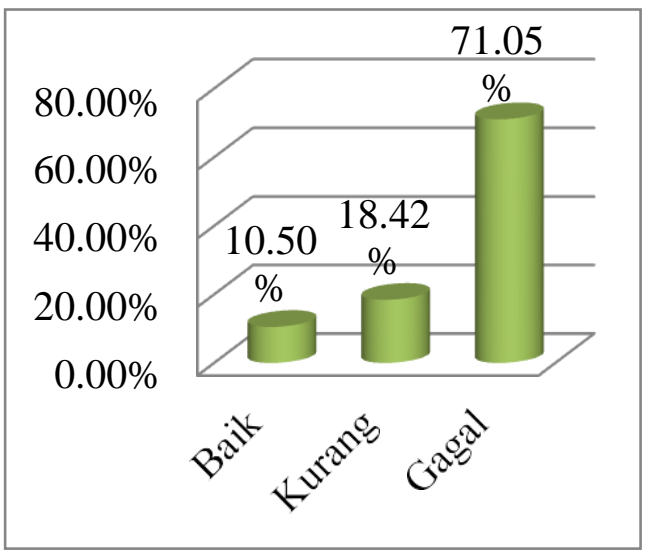

Tes akhir pada kelas eksperimen

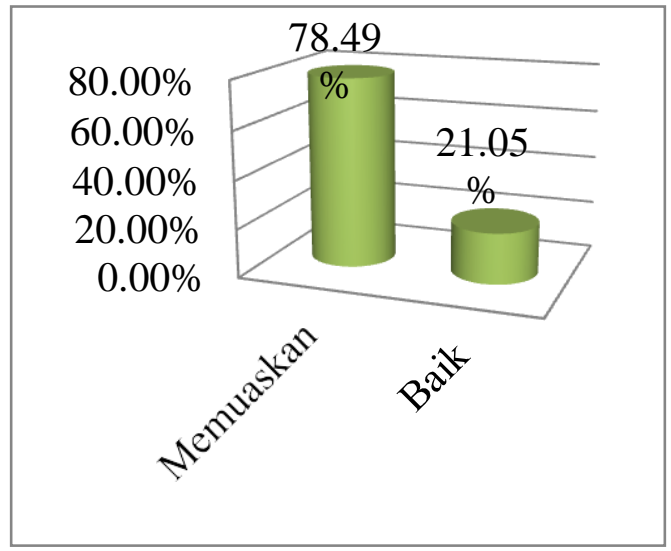

Gambar 3.

\section{Grafik PAP skala 5 pada kelas eksperimen}

\section{B. Pengujian Prasyarat Analisis}

a. Uji normalitas

Uji normalitas data tes akhir untuk siswa kelas eksperimen dengan rumus chikuadrat diperoleh nilai dan karena maka kesimpulan data berdistribusi normal. Berdasarkan uji normalitas data menunjukan bahwa kemampuan representasi matematis siswa data berdistribusi normal maka pengujian hipotesis digunakan uji perametrik yaitu uji t.

b. Pengujian Hipotesis

Berdasarkan uji normalitas diketahui data dalam penelitian ini adalah berdistribusi normal yang selanjutnya dilakukan uji hipotesis. Sehingga statistik uji yang digunakan adalah statistik uji parametrik yakni uji t. Dapat diperoleh $\mathrm{t}_{\mathrm{hit}}=2,88 \mathrm{dan}$ $\mathrm{t}_{\mathrm{tab}}=1,684$ maka $\mathrm{t}_{\text {hit }}>\mathrm{t}_{\mathrm{tab}}$. Dengan demikian terdapat peningkatan kemampuan representasi matematis siswa melalui model pendekatan RME pada siswa SMP 
Negeri 4 Mangoli Selatan.

\section{Pembahasan Hasil Penelitian}

\section{Kemampuan representasi matematis siswa kelas VII pada materi Diagram Venn melalui pendekatan matematika Realistik.}

Setelah peneliti melakukan pembelajaran dengan pendekatan RME, siswa diberikan tes akhir untuk mengetahui kemampuan representasi matematis siswa. Hasil akhir kemampuan representasi matematis siswa yang berjumlah 38 yang dilaksanakan pada hari sabtu tanggal 28 Mei 2016 terdapat peningkatan. Hasil tes akhir pada kelas eksperimen setelah dikonversi ke PAP skala 5 terdapat 30 siswa $(78,94 \%)$ kualifikasi memuaskan dan 8 siswa ( $21,05 \%$ ) kualifikasi baik. Peningkatan jumlah siswa yang tuntas disebabkan sebagian besar siswa telah memahami materi diagram venn.

Berdasarkan hasil tes akhir dapat diketahui kualifikasi kemampuan representasi matematis siswa kelas VII untuk indikator pertama menyajikan kembali data atau informasi dari representasi kata-kata ke representasi diagram dan indikator kedua menyatakan masalah dalam bentuk persamaan atau model matematis. Deskripsi hasil kerja siswa berdasarkan indikator kemampuan representasi dapat diperoleh sebagai berikut:

a. Menyajikan kembali data atau informasi dari representasi ke reresentasi diagram.

Dari 38 Siswa yang berkualifikasi memuaskan sebanyak 30 siswa atau $(78,94 \%)$ pada kelas RME, dalam hal ini siswa telah memahami materi yang telah diajarkan sehingga mampu menyelesaikan soal sesuai dengan indikator pertama menyajikan kembali data atau informasi dari representasi ke representasi diagram.

\section{Gambar 4.}

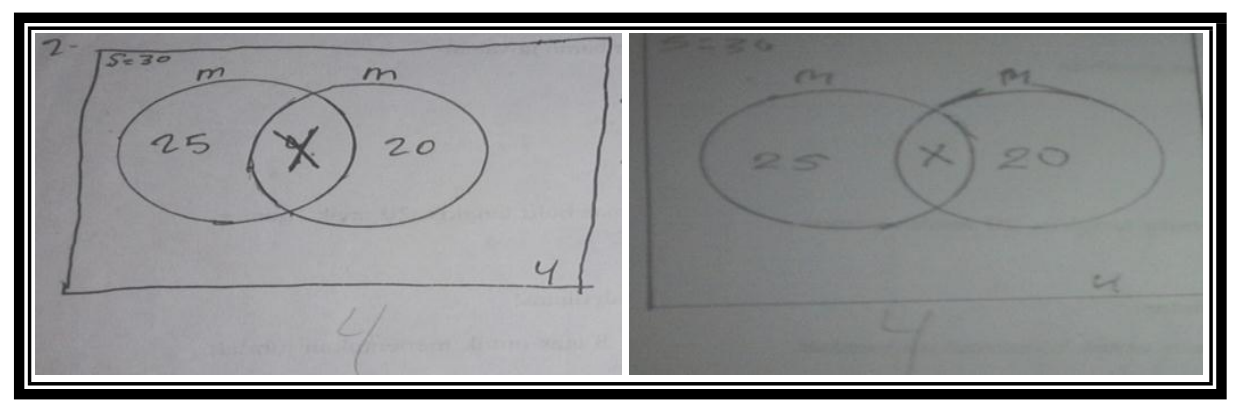

Hasil kerja siswa dalam menyajikan kembali data atau informasi dari 


\section{representasi ke representasi diagram venn}

Dari hasil kerja siswa di atas siswa mampu mendiskripsikan representasi katakata ke representasi diagram dengan benar.

b. Menyatakan masalah dalam bentuk persamaan atau modelmatematis

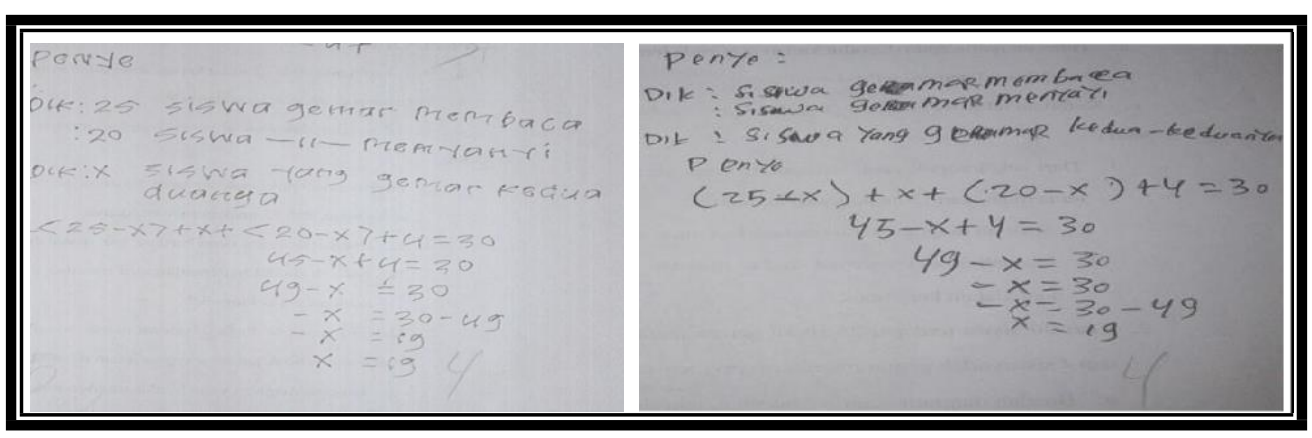

\section{Gambar 5.}

\section{Hasil kerja siswa dalam menyelesaikan masalah dalam bentukpersamaan}

\section{atau model matematis}

Dari hasil kerja siswa di atas siswa dapat menyelesaikan masalah dalam bentuk persamaan atau model matematis dijawab dengan benar dan tidak ada kesalahan sesuai dengan prosedur yang diinginkan. Keberhasilan siswa pada indikator kedua ini menunjukkan bahwa siswa benar-benar memahami masalah yang disajikan sehingga dapat menyelesaikan masalah dalam bentuk persamaan atau model matematis dengan benar.

a. Menyajikan kembali data atau informasi dari representasi kata-kata ke representasi diagram

Berkualifikasi baik 8 siswa atau $(21,05 \%)$ pada kelas RME siswa telah memahami materi yang telah diajarkan sehingga mampu menyelesaikan soal sesuai dengan indikator pertama menyajikan kembali data atau informasi dari representasi ke representasidiagram.

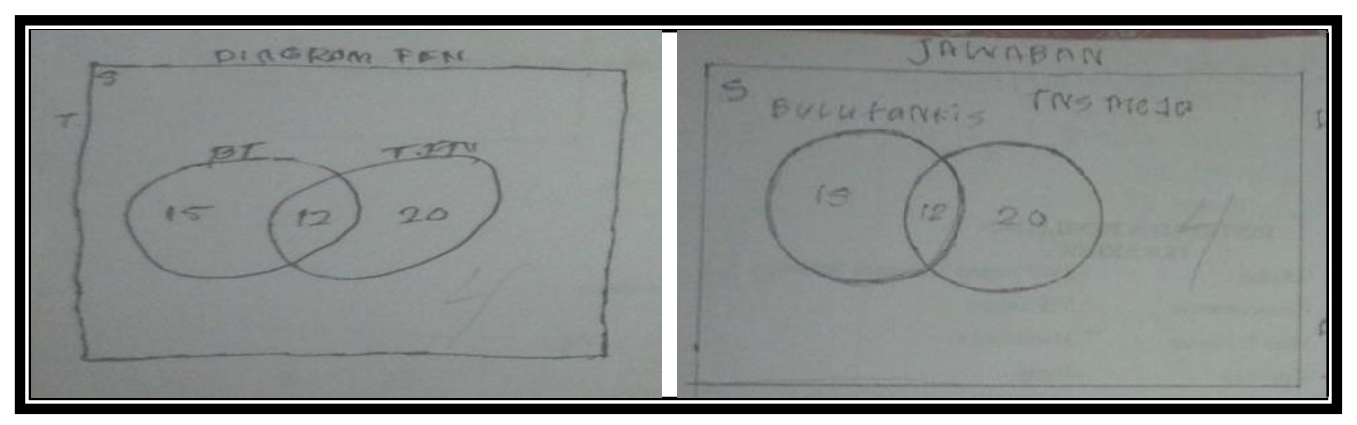




\section{Gambar 6.}

\section{Hasil kerja siswa dalam menyelesaikan kembali data atau informasi dari} representasi kata-kata ke representasi diagram

Dari hasil kerja di atas siswa mampu mendeskripsikan kembali data atau informasi dari representasi kata-kata ke representasi diagram dengar benar.

b. Menyatakan masalah dalam bentuk persamaan atau modelmatematis

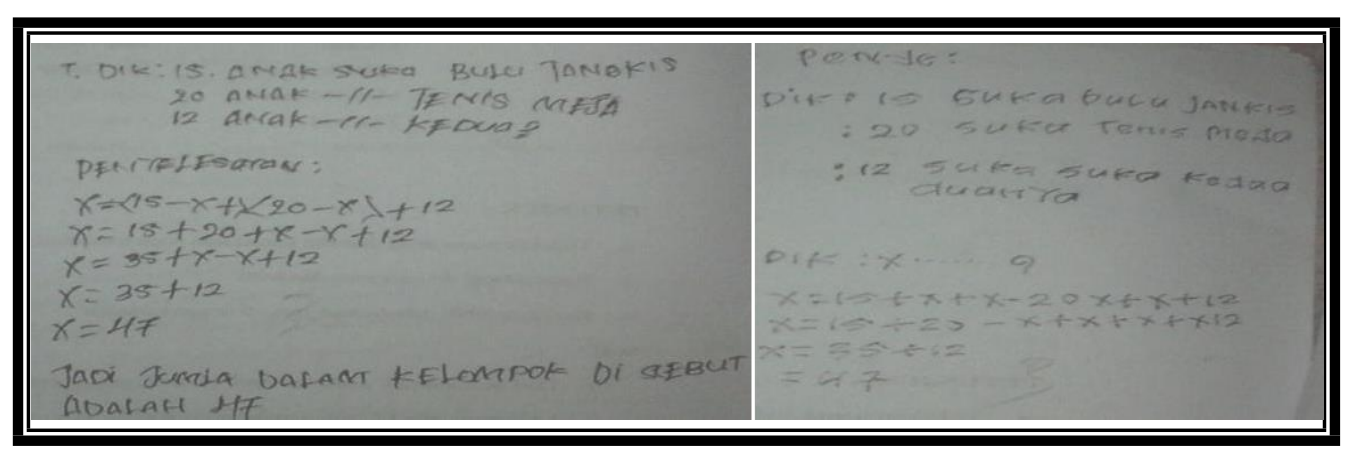

Gambar 7.

Hasil kerja siswa dalam menyelesaikan masalah dalam bentuk persamaan atau model matematis

Dari hasil kerja siswa di atas siswa sudah mampu memahami materi yang telah diajarkan tetapi kurang teliti dalam menyelesaikan model matematika. Pada indikator kedua ini jawaban akhir siswa sudah benar tetapi terdapat kesalahan pada menyelesaikan persamaan atau model matematika.

\section{Pendekatan matematika Realistik dapat meningkatkan kemampuan} reprsentasi matematis siswa dalam menyelesaikan Diagram Venn

Pendekatan RME dapat meningkatkan kemampuan representasi matematis siswa kelas VII SMP Negeri 4 Mangoli Selatan pada tes akhir yang diperoleh Gain = 0,88 yang diinterpretasikan tinggi dengan nilai rata-rata siswa 93,94. Selain itu, peningkatan kemampuan representasi matematis dapat dilihat dari hasil kerja siswa sebelum menggunakan model dan sesudah menggunakan model.

1. Menyajikan kembali data atau informasi representasi kata-kata ke representasi diagram

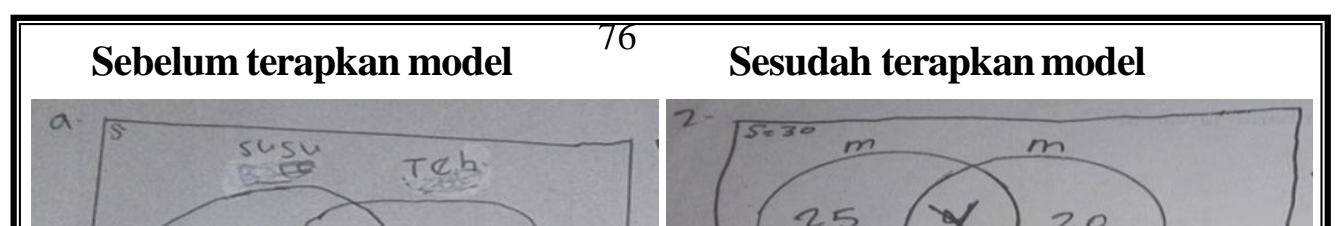




\section{Gambar 8.}

\section{Hasil kerja siswa dalam menyajikan kembali data atau informasi dari representasi kata-kata ke representasi diagram}

Dari hasil kerja siswa di atas pada gambar 7 dapat diketahui bahwa indikator pertama sebelum terapkan model siswa berkualifikasi kurang 7 siswa $(18,42)$ belum mampu memahami menyajikan kembali data dari representasi ke representasi diagram, dan hasil kerja siswa sesudah terapkan model siswa berkualifiasi memuaskan 30 siswa $(78,94)$ sudah mampu memahami menyajikan kembali data dari representasi ke representasi diagram.

2. Menyatakan masalah dalam bentuk persamaan atau modelmatematis

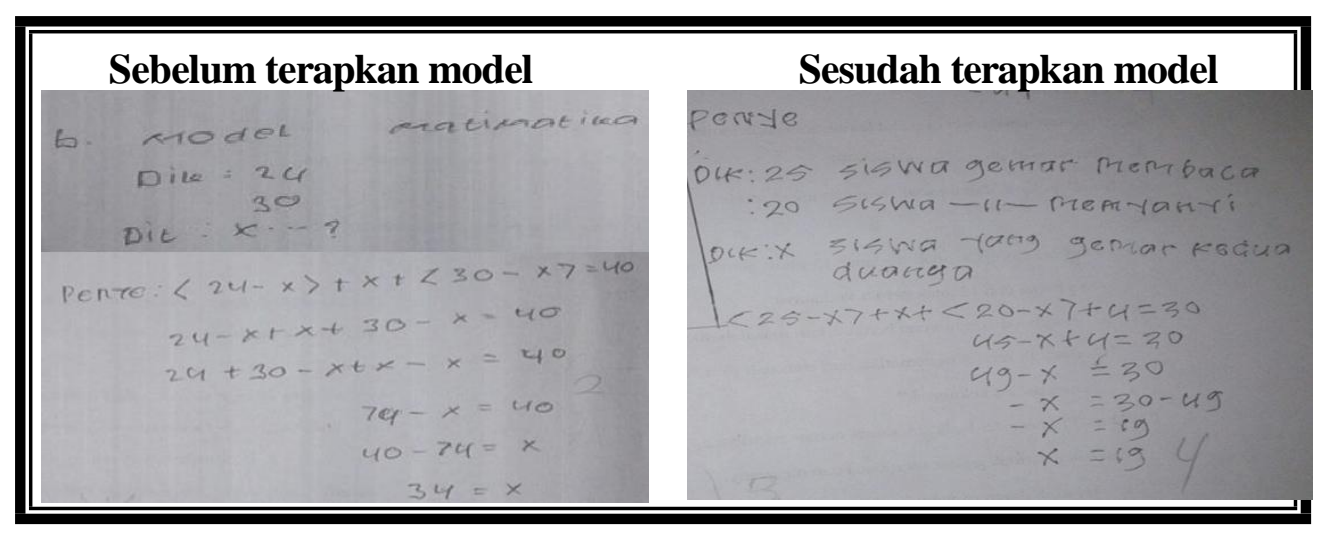

\section{Gambar 9.}

Hasil kerja siswa dalam menyelesaikan masalah dalam bentuk persamaan atau model matematis

Berdasarkan hasil kerja siswa di atas dapat diketahui bahwa pada indikator kedua sebelum terapkan model siswa belum mampu memahami masalah dan belum 
mampu menyelesaikan masalah dalam bentuk persamaan atau model matematis, dan sesudah menerapkan model siswa mampu memahami masalah dan mampu menyelesaikan masalah dalam bentuk persamaan atau model matematis, nampak bahwa sesudah menerapkan model siswa mampu menyelesaikan masalah dalam bentuk model matematika.

Pendekatan RME dapat meningkatkan kemampuan representasi karena Pendekatan Realistic Mathematic Education adalah suatu pendekatan yang menempatkan realitas dan pengalaman siswa sebagai titik awal pembelajaran dimana siswa diberi kesempatan untuk mengkonstruksi sendiri pengetahuan matematika formalnya melalui masalah-masalah realitas yang ada. Dengan pendekatan ini siswa 
tidak hanya mudah menguasai konsep dan materi pelajaran namun juga tidak cepat lupa dengan apa yang telah diperolehnya tersebut. Pendekatan ini pula tepat diterapkan dalam mengajarkan konsep-konsep dasar.

Kemampuan representasi matematis adalah salah satu kemampuan yang sangat penting bagi siswa dan merupakan salah satu tujuan yang hendak dicapai dalam pembelajaran matematika di sekolah. Representasi sangat berguna dalam membantu siswa menyelesaikan sebuah masalah dengan lebih mudah. Representasi juga berguna sebagai sarana mengkomunikasikan gagasan atau ide matematik siswa kepada siswa lain maupun kepada guru.

\section{KESIMPULAN}

Berdasarkan hasil penelitian dan pembahasan yang diperoleh dari sampel yang berjumlah 38 siswa kelas VII SMP Negeri 4 Mangoli Selatan dengan menggunakan pendekatan RME yang diberikan dalam bentuk tes dapat disimpulkan sebagai berikut:

1. Kemampuan representasi matematis siswa terhadap materi diagram venn melalui pendekatan pembelajaran RME terdapat siswa berkualifikasi memuaskan, baik, cukup, kurang dan gagal.

2. Pendekatan RME dapat meningkatkan kemampuan representasi matematis siswa kelas VII SMP Negeri 4 Mangoli Selatan pada materi diagram venn. 


\section{Daftar Pustaka}

Hamalik, 2004. Proses Belajar Mengajar : Metode Struktur. Yogyakarta : Bumi Aksar Hudiono, Bambang. 2005. Peran Pembelajaran Diskursus Multi Representasi Terhadap Pengembangan Kemampuan Matematik dan Daya Representasi pada Siswa SLTP. Bandung : DisertasiUPI

Laramla. 2014. Peningkatan Kemampuan Berpikir Kreatif Matematis Siswa Melalui Pendekatan Pembelajaran Realistic Mathematic Education (RME) Pada Materi Balok. Skripsi, Universitas Khairun Ternate. tidak diterbitkan

Nurhayati. 2013. Meningkatkan Kemampuan Representasi dan Berpikir Matematis Siswa SMP Melalui Pendekatan Pendidikan Matematika Realistik. Universitas Pendidikan Indonesia. Jurnal Repository, Vol (2), No 4, 15-42

Sugiyono, 2012. Metode penelitian kuntitatuif kualitatif dan $R \& D$. Bandung : alfabeta Sundayana R. 2014. Statistik Penelitian Pendidikan. Bandung: Alfabeta

Thoha, M. C. 2003. Tekhnik Evaluasi Pendidikan. Jakarta: Raja Gravindo Persada 